\title{
COMMUNICATIVE COMPETENCIES OF MANAGERS IN HEI ON COMPONENTS OF METHODOLOGICAL CONTENTS OF ADMINISTRATIVE MANAGEMENT
}

\author{
V. Tymoshenko, O. Slabetskyi, N. Ridei, N. Tytova
}

The paper specifies the definition of "competence" of executive managers and positional, professional and social types of the general system competence are separated. The communicative competence structure in managers at higher educational institutions for realizing communicative interaction of participants of the professional training educational process is concretized by methodological content components of administrative management, namely administrativeorganizational managerial system relations (descending potential of indirect administrative-organizational communication of a policy of higher educational institutions, coordination-subordination architectonics of the "administrative apparatus", ascending potential of administrative effect at organizing institutional projects), internal system relations (descending administrative-organizational communications of a political strategy of higher educational institutions, potential of ascending administrative-organizational communications for modernization of educational-scientific university systems) and external system relations (sphere of external interaction and system analysis of modern scientific data as to a qualitative external condition of higher educational institutions, world community access to administrativeorganizational communication of higher educational institutions with self-government bodies). There are separated communication types of coordination-subordination architectonics of institutional organization of higher educational institutions: administrative-organizational, managerial and process-organizational communications; a structural-logic scheme of mutual influence in contents - administrative-organizational managerial system, internal and external system relations in the "aim tree" of administrative regulation for effective educational policy and quality policy by means of administrative-organizational communications and at realization of the communicative competence of managers at higher educational institutions is projected in the author modification

Keywords: communicative competences, communications, managers' professional training, structural-functional scheme, "aim tree", administrative management

Copyright (C) 2021, V. Tymoshenko, O. Slabetskyi, N. Ridei, N. Tytova.

This is an open access article under the CC BY license (http://creativecommons.org/licenses/by/4.0).

\section{Introduction}

The Ukrainian legislation defines first-turn priorities on problems of realizing the National informatization program, including creating the normative-legal base of informative-technological support including the protection system of author rights and personal data, elaborating national standards in the branch of economy and science, economics and innovatics digitalization, forming an information-telecommunication infrastructure, network-platform organization of institutional life activity first of all with harmonization of mixed and network forms of main roads of modern scientific information data transmission. System development of new translation channels, fiber-optic and satellite systems of interactive online connections and also architectonics of the computer-organized network system of education, science and innovatics and academic culture as a general component of the world network of scientific-metric Internet-resources favors information safety arrangements for sociocultural, educational-scientific forms and systems, web- and scientific-metric potential of academic schools of higher educational institutions (then - HEI), including personal protection of information data of either an applicant of education and scientific services or participant of the educational process or parties of the quality management system of education and scientific research and other engaged representatives of professional employment throughout life.

\section{Literary review}

A methodological basic for studying administrative-organizational communications is works by the scientists: M. Armstrong [1] (theoretical and practical management of human resources), P. Boxall [2] (use of ecommunications in the global context of society interaction, based on new cultural and technological developments of information-communication technologies), D. Hebert [3] (motivation, estimation of a staff satisfaction level and management); among native scientists Y. Kovbasiuk. V. Troschinsky, Y. Surmin, M. Bilynska [4] and other studied the methodology of state management as a scientific knowledge branch.

Substantiation of theoretical-methodological principles of competence interpretation has been realized through the prism of introduction of the integrated threephase methodology for prognostication of future requirements to the future specialists' competence [5], at the same time thematic studies of obstacles of organizational communications, based on the conceptual model with the aspects: structural (centrality and officialdom), behavior (perceptive and human barrier) and context (cultural and technical barriers) [6, 7] give grounds to 
concretize the managers' communicative competence structure for realizing communicative interaction of participants of the professional training educational process. A background of this study is author works, substantiating theoretical and methodological formation aspects of the system of postgraduate education and research, based on steadiness, expert evaluation in algorithms of individual and collective examinations of plan and development program strategies [8, 9], specificity of effective management of learning-cognitive activity of future specialists under pandemic conditions in the postmodern education model [10].

\section{Research aim and tasks}

The aim of this study is to discover the communicative competence structure of HEI managers in realization of communicative interaction of participants of the professional training educational process by methodological content components of administrative management.

To accomplish the aim, the following tasks have been set:

- to separate communication types of coordination-subordination architectonics of HEI institutional organization;

- to elaborate a structural-logic scheme of mutual influence spheres and aims of administrative-organizational communications in the author modification.

\section{Materials and methods}

Research methods were chosen as content-, eventanalysis of theoretical-methodological principles of scientific study of the conceptual-categorical apparatus of the future managers' communicative connection managers at HEI by the source base of psychologicalpedagogical, fundamental-philosophical, social-political scientific literature.

Content-analysis as a method of applied study of theoretical-methodological aspects of a scientific problem provided separation of content-information scientific data and favored results interpretation. The method of event-analysis was used for studying the information foundation of communicative interaction of management organization at HEI and determined by the classification signs: manager prevalence of a subject phenomenon of leadership; functional-purposeful destination of a management subject; organizational admin-managerial influences of object-subject activity.

\section{Research results and their discussion}

Interpretation of the notion "competence" was concretized by theoretical and methodological principles; it is formulated as an ability to professional realization of acquired modern scientific knowledge at the system activity of communicative interaction of the certain complex of professional works or intensification management of its realization, providing quality and efficiency management of the relevance educational process by functional destination. The interpretation of a competent specialist is indivisibly connected with a competence or his/her professional ability to competent decision making in the sphere of science and knowledge of management in the sphere of education, science and innovatics and its information-technological support. The manager's com- petence is vectored in spheres of using business, management, public administration and their organization levels. Types of the general-system competence of executive managers:

- positional competence as a quality of an official, providing the effective professional correspondence of the individual professional potential;

- professional competence includes the information-technological communicative readiness at providing functional professionalism with specialization;

- social competence reflects communicative relations of professional activity processes and characterizes the future managers' ability to corporative interaction, effective communication of the coordinationsubordination architectonics of institutional organization for attaining partial goals and strategic aim of an institution's mission, is based on managers' communicative possibilities to manifest business culture of academic communication.

Administrative-organizational communications administrative process of mutual exchange and access to information resources of modern scientific knowledge and academic experience in formalized and informal connection channels of social categories of interested persons, oriented on coordination-subordination relations of system and intersystem interaction for solving problem tasks and harmonizing the professional training educational process and attaining aims. The strategic aim of educational-scientific systems modernization at HEI is institutional analysis of the HEI architectonics, responsibility of the HEI administrative apparatus and management, process administration and public management at HEI, qualitologic metrics and monitoring of the academic potential and relevance of the educational-scientific process, administrative, organizational-managerial procedure of improving professional training of specialists and administrators at HEI.

Administrative-organizational communications are an inalienable component of admin-management administrators and managers at levels and in structuralorganizational administration links use prognostication, planning, organizational-managerial administration of purpose semantics, coordination-subordination interaction of control, monitoring, audit, passport system, certification, standardization, licensing and marketing of educational and scientific programs, services and products for realizing the purpose component of HEI strategic development and purpose itself.

Classification signs of administrativeorganizational communications (in processes and flows of network interactions):

- by efficiency criteria of the management system - system-intersystem relations of strategic marketing and management;

- by interaction with self-government and public;

- by semantics of subordination-coordination relations of the linear-vertical dependence, on the ascending potential (on the vertical from below), system-horizontal connections of structural-organizational sections (horizontal and also interstructural organization) according to the content-methodological filing with modern scientific information (of directive, information-analytic, metricevaluative, report-monitoring and system-coordinating 
type in network cannels of information translation (verbal-non-verbal);

- by mechanisms of formal-informal transmission of modern scientific knowledge.

The spheres of organization-administrative communications are presented in table 1 and fig. 1 and im- proved by M. Armstrong [1]. The corner function of administrative-organizational communication is giving social support - engaging of a person and his/her awareness of care and preoccupation, personal propagation of social of social recognition of an education applicant as a future specialist and professional respect production.

Table 1

Content of admin-management at levels of system and intersystem interaction of HEI managers' communicative competences

\begin{tabular}{|c|c|c|}
\hline $\begin{array}{l}\text { Administrative-organizational manageri- } \\
\text { al system relations }\end{array}$ & Internal system relations & External system relations \\
\hline $\begin{array}{l}\text { - Descending potential of indirect adminis- } \\
\text { trative-organizational communication as to } \\
\text { purposeful organization policy, strategic } \\
\text { planning and marketing, administrative } \\
\text { budgeting according to address connection } \\
\text { of interested executors. } \\
\text { - Coordination-subordination architectonics } \\
\text { of the admin-apparatus as to administration } \\
\text { of official administrative-organizational } \\
\text { regulations of direct influence from a leader } \\
\text { to a subordinate according to functional } \\
\text { authorities and official duties. } \\
\text { - Ascending potential of administrative in- } \\
\text { fluence in direct, indirect, intermediate } \\
\text { communicative influences of administrative } \\
\text { organization as to HEI projects, presenta- } \\
\text { tions, consulting, advising and scientific- } \\
\text { methodical offers of services and scientific- } \\
\text { methodical support of organizational- } \\
\text { managerial procedures of administrative } \\
\text { regulations of educational policy and one of } \\
\text { HEI quality. } \\
\text { - External public-administrative indirect } \\
\text { communications of the ascending basis that } \\
\text { provide the admin-apparatus in social- } \\
\text { administrative data as to the effectiveness of } \\
\text { learning programs and scientific services at } \\
\text { HEIs and their portative lability and also } \\
\text { relevance of the educational process }\end{array}$ & $\begin{array}{l}\text { - Descending administrative- } \\
\text { organizational communications, } \\
\text { propagating and promulgating the } \\
\text { mission, philosophy as to a politi- } \\
\text { cal strategy and system activity of } \\
\text { HEI. } \\
\text { - Potential of ascending adminis- } \\
\text { trative-organizational communi- } \\
\text { cations, noticed by subordinates' } \\
\text { reaction on strategic and static } \\
\text { actions as to their professional use } \\
\text { at providing modernization of } \\
\text { HEI educational-scientific sys- } \\
\text { tems }\end{array}$ & $\begin{array}{l}\text { - Spheres of external interaction } \\
\text { and system analysis of modern } \\
\text { system analysis of modern scien- } \\
\text { tific data as to the qualitative exter- } \\
\text { nal condition of HEI (academic } \\
\text { potential and traditions, web-metric } \\
\text { presentation of professional reputa- } \\
\text { tion, scientific-metric profiling of } \\
\text { academic community representa- } \\
\text { tives, observance of prestige, aca- } \\
\text { demic virtue and ethics). } \\
\text { - Provision of access for the world } \\
\text { community as to administrative- } \\
\text { organizational communication of } \\
\text { HEI with self-government bodies } \\
\text { with the wide public amplitude of } \\
\text { different categories in types of na- } \\
\text { ture use and at management types } \\
\text { of modernization of educational- } \\
\text { scientific systems in transboundary } \\
\text { interaction of society of social sci- } \\
\text { entific knowledge of advanced } \\
\text { information type }\end{array}$ \\
\hline
\end{tabular}

Administrative-organizational communication systems are ranked by both internal network means of the internet-access, system-corporative bibliographic sources and translating-didactic information transmission at meetings (of instructive-discussing, trainingseminar, public-probation and advising types). Administrative-organizational communication is realized using communicative networks as an integral totality of information flows of synergism of the HEI educationalscientific process. Communicative functions at HEI are provided by means of analytic information. Providing access to analytic means competence availability to information data, such as ones, obtained from verified reliable correlated facts, presented as a response to a concrete problem question, it must be pertinent that is directly proved. The reliability of distinctly established information is taken into account among other verification factors, namely joint combination and concretization of separation of diverse factors, maximally corre- sponding to the difficulty of the problem, that is a research subject and gives a possibility to realize an information-analytic description of a system analysis object, to determine regularities and tendencies by modeling (primary and secondary) - the primary one is understood as separated situation events of qualitativequantitative characterization of subjects, actions of socio-political and public retranslators of administrative management (information is of weak architectonics). A characteristic of a problem phenomenon is studied due to methods of getting an initial informative-analytic data base - observations (factorization, description of phenomena and processes, socioeconomic and political reality), testing (method of obtaining parameters of typical classification signs and properties, based on standard tasks), interviewing (questioning method by the technique of interpersonal communication diagnostics), sociometry (diagnostic metrics of interpersonal and group informal relations between collectives). 


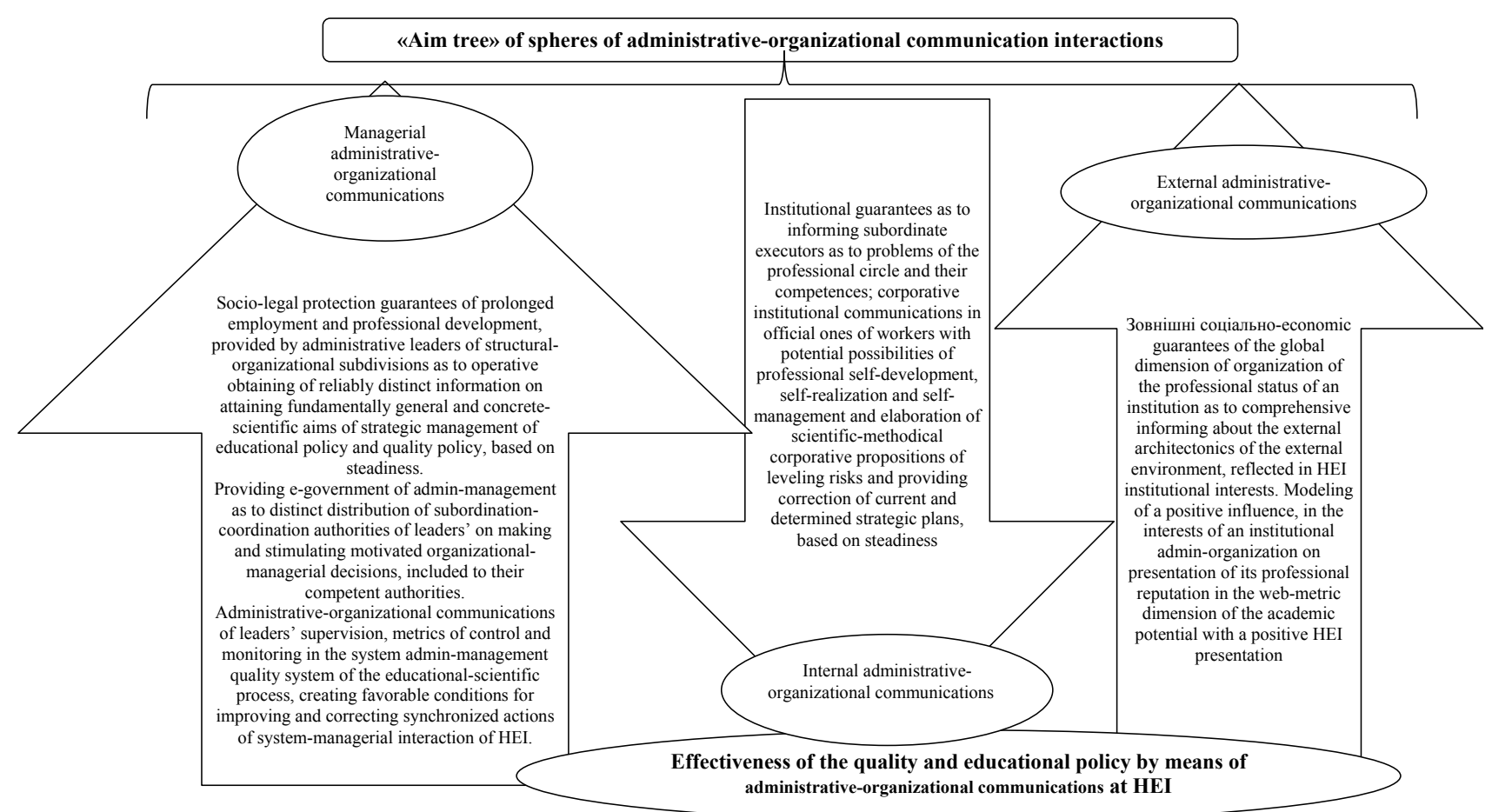

Fig. 1. Structural-logic scheme of mutual influence and aim spheres of administrative-organizational communications, based on M. Armstrong's propositions, modified and improved by the authors

The derivable (secondary) base of analytic information is collection, generalization and systematization of logic analysis results and ranking of primary informative-analytic data of participants (direct and external experts, analysts, consultants). Methods of getting secondary analytic information are:

- qualitative analysis (traditional analysis of documents with text interpretation by form and content of a concrete specialist);

- qualitative-quantitative analysis (contentanalysis of formal scientific cognition of literary sources for establishing typical units of information components, related to the aim constituent of a study);

- quantitative analysis (strategic systematization and generalization of quantitative information for diagnosing causal relations);

- event-analysis (study of the dynamics of processes and phenomena or their algorithmization in the dynamics for establishing prevailing tendencies of objects' interaction in a concrete situation);

- cognitive mapping (as to establishing typical features of situation understanding by severance of correspondence between structural components of a text and an author's prevailing idea).

Administrative communications - total information integrity of the process of intersubject managerial activity of vertical-horizontal interaction in the systemintersystem environment of direct information exchange using modern communication (mutual understanding) means. Realization of semantics of administrative communications at HEI provides the functionality:

- information as to transmission of data of necessary made decisions of classification identification and methodology of alternative evaluation;
- behavior motivation of functions, inducement of participants of the educational-scientific process and administrative-managerial activity to system-administrative actions of persuasion, encouragement, motivation, instruction, pressure, compulsion;

- supervising-controlling observation over behavior of participants of the educational-scientific process of administrative-managerial activity at HEI in bases of architectonic and methodological hierarchy of formal and informal subordination;

- Existential-expressive, providing noncompensatory emotional losses and expression of feelings, experience, personal attitude to satisfaction of needs of the social dimension.

Administrative communications reflect perception, translation, understanding, assimilation and systematization of modern scientific information data transmission. These processes provides synchronization in the administrative managerial apparatus by connecting links, coordination-subordination actions of administrativeleaders and subordinated executors or between administrative leaders or external environment, vitally providing a connecting link of synergetic interaction between participants of the educational-scientific process at HEI. Classification signs of administrative communications provide separation of organizational-managerial, supersystem-external, internal-system, coordinationsubordination (horizontal-vertical), ascending and descending realization potential, interpersonal personification, formally and informally regulated ones.

Process-organizational communications are provides by leaders in the system of promulgation of modern scientific information with proper access and its social transformation, corporative subject organization and ex- 
ternal institutional interaction in open systems of HEI sociocultural forms. Communications are a necessary instrumental coordination means of system activity of vertical-horizontal management of system analysis of components of the information-analytic system for methodical support of the educational-scientific process of managers' professional training. External processorganizational communicative interaction provides exchange of practically useful experience, scienceintensive information between organizational formation of institutions and the environment and its functioning and also internal process-organizational communication between management subjects in the spheres of education, science and innovatics at different organizational architectonics levels.

Internal process-organization communications are coordinated at levels of managing structuralorganizational subdivisions, official responsibility within the staff policy, network organization of communication channels in the process of obtaining desirable, adjacent, cross and additional qualifications by applicants of educative, consulting-advisory services, processes of egovernment and documents exchange and also functioning of information connection means. Contentmethodological interaction is in informative-analytic, administrative-managerial, public-administrative, technological-process functions of an organization. An information-analytic one provides practically useful exchange in subject-managerial system activity by modern scientific data for making strategic decisions of sustainable socioeconomic, eco-safe development. Internal system communications are divided in ones of verticalhorizontal and diagonal interaction (vertical includes ascending and descending ones). The first ones realize aims of promulgation of general tasks of the HEI system activity for workers, delegation of official instructions as to professionally important tasks, providing awareness of corporative technologies of administrative-organizational communication at work and their coordination with other institutional tasks, providing access to information data as to management procedures and methods of professional tasks realization, methodical support of continuous formation of workers' communicative competences as to managing information and results of HEI activity in the system of management quality of HEI educationalscientific systems and their modernization. Horizontal ones are provided in structural-organizational subdivisions by empowered officials by architectonic hierarchy levels, when information exchange is provided by educational and quality policy through qualitologic management subjects. Diagonal communications provide intersubject HEI management and are at architectonic organization levels. Personified interpersonal communications of interaction provide interpersonal closeness and exchange, motivated, interested information, prevailing as a channel of verbal persuasion of its translation with qualification signs - operative achievement of acmeologic persuasion of an addressee, selective interpersonal operative formation of favorable translation of modern scientific information within interpersonal contacts and bifurcation disturbance of respondents' boundaries.

Interpersonal communications of personified interaction regulate a presentation form and acceptable style of mutual understanding (by the persuasion talent of a retlanslator - mentor to a respondent, applicant of education, realization of feedback potential of non-linear, system, intersystem and supersystem interaction. The effectiveness of process-organizational communications is provided by the level of synergetic coordination of directly dependent feedback, organizing a retranslator's possibility to check up conscious understanding of an applicant in trustworthiness of interpreted information according to students' conclusions.

Interpersonal communications are divided in formal and informal. Formal ones are provided by the HEI organizational architectonics and illustrate processes of information channels of system activity. Informal ones are not provided by the institutional structure.

Communicative managerial competences, formed in HEI managers, are used in means of written, nonverbal, organoleptic, tactile communication, formed in report-plan documents, safety leaflets, scientific lectures, announcements and reference information of public presentation in media; verbal - of dialog and discussion character of interpersonal content, phone conversations, public speaking, professional meetings, non-engaged forums and assemblies of direct interpersonal communication. The aforesaid communications are a complex synergetic integrity and synchronized dynamic phenomenon, considered as an interaction, process of scientific problem study - communicative process of positive useful information exchange in the set of participants of the HEI system-managerial activity.

Components of information exchange are entrance channels - an information translator, a person, producing, collecting and retranslating information, information message - code-symbol presentation of an information encryption, respondent-receiver - an addressee, a person of the interested information circle. The effectiveness of the information communication process is determined by stages of hypothesis idea production, when a translator decides which of them is worth realizing as a subject of the informational useful exchange, symbolization (coding) - the process of transforming a hypothetic idea in sings, visual images, schematic pictures, forms, sounds of translation languages, choice of retranslation channels by means of signal direction from a retranslator to a respondent, spreading and propagation of information provide finding a message by a retranslator and transmission channels at favoring the movement of giving information towards an addressee-receiver, deciphering as a process of informing a receiver, transforming perceived signs and symbols in a concrete sound-visual, tactile, non-verbal information by receiver's interpretation of a message by decoding symbols in certain relevant meanings, feedback as role exchange between communication process participants, in which the cycle repeats in the reverse direction.

For trustworthiness of the relevant result, feedback closes the communicative outline and makes possible a conscious initial message, increasing the effectiveness of the communication process. Its base provides establishing of the purposeful communication component, distribution of the aim tree amplitude for determining achievement ways, planning of resource saving and situation costs of concrete problems and actions, directed on solving complicated problem and critical situations, 
organization of short-term, current and determined plans of system actions, coordination of relations, communicative process in the system process interaction of components of direct participants, supervision and control over the process of realization, improvement and correction of relevant results of process communications.

\section{Conclusions}

The communicative competence structure of HEI managers in realization of communicative interaction of participants of the professional training educational process by methodological content components of administrative management has been specified that allowed:
- to separate communication types of coordination-subordination architectonics of HEI institutional organization: administrative-organizational, managerial and process-organizational communications;

- to project the author modification of the structural-logic scheme of mutual influence spheres in the contents - administrative-organizational, internal-system and external system relations in the "aim tree" of administrative regulation and effective educational and quality policies by means of administrative-organizational communications and at realizing the communicative competence of HEI managers.

\section{References}

1. Armstronga, M. (2010). Praktika upravleniia chelovecheskimi resursami. Saint Petersburg: Piter, 848.

2. Boxall, P. (2013). Twenty-First-Century Fiction: A Critical Introduction. Cambridge: Cambridge University Press, 275. doi: http://doi.org/10.1017/cbo9780511902727

3. Gerbert, D., Rozenshtil, fon L. (2006). Organizatsionnaia psikhologiia. Chelovek i organizatsiia. Kharkiv: Izd-vo «Gumanit. Tsentr» O. A. Shipilova, 624.

4. Kovbasiuk, Yu. V., Surmin, Yu. P., Nadolishnii, P. I. et. al. (Ed.) (2011). Entsyklopediia derzhavnoho upravlinnia. Vol. 2 : Metodolohiia derzhavnoho upravlinnia. Kyiv: NADU, 692.

5. Robinson, M. A., Sparrow, P. R., Clegg, C., Birdi, K. (2007). Forecasting future competency requirements: a three phase methodology. Personnel Review, 36 (1), 65-90. doi: http://doi.org/10.1108/00483480710716722

6. Kheirandish, M., Abbaszadeh Avilagh, H., Nazemi, N. (2017). An empirical study of the pathology of organizational communications based on three branches model: A case study. Arab Economic and Business Journal, 12 (2), 81-92. doi: http://doi.org/10.1016/j.aebj.2017.10.001

7. Tunay, T., Özlem, K. (2020). On the Models of Communicative Competence. Proceedings of GLOBETSonline: International Conference on Education, Technology and Science, 86-96.

8. Ridei, N. M., Serhiienko, V. P. (Ed.) (2017). Multymodusni zasady pisliadyplomnoi osvity dlia staloho rozvytku. Kyiv: Vyd-vo NPU imeni M. P. Drahomanova, 641.

9. Ridei, N. M. (Ed.) (2018). Upravlinnia systemamy pisliadyplomnoi osvity dlia staloho rozvytku. Kyiv: Vyd-vo NPU imeni M. P. Drahomanova, 672.

10. Zozuliak-Sluchyk, R., Tytova, N., Kozliuk, O., Salata, H., Ridei, N., Yashnyk, S., Litvinchuk, S. (2021). Anthology of Forms of Management of Students' Cognitive Activity Institutions of Higher Education in the Use of Modern Information Technologies. Systematic Reviews in Pharmacy, 12 (1), 235-241.

Received date 29.12.2020

Accepted date 26.01.2021

Published date 30.01.2021

Valentyna Tymoshenko, Postgraduate Student, Department of Adult Education, National Pedagogical Dragomanov University, Pirogova str., 9, Kyiv, Ukraine, 01601

E-mail: tymoshenko_vi@ukr.net

Oleksandr Slabetskyi, Postgraduate Student, Department of Adult Education, National Pedagogical Dragomanov University, Pirogova str., 9, Kyiv, Ukraine, 01601

E-mail: ukraviatekstil@gmail.com

Nataliia Ridei, Doctor of Pedagogical Sciences, Professor, Department of Adult Education, National Pedagogical Dragomanov University. Pirogova str., 9, Kyiv, Ukraine, 01601

E-mail: ridei.nataliia@gmail.com

Nataliia Tytova, Doctor of Pedagogical Sciences, Associate Professor, Head of Department, Department of Theory and Methods of Vocational Training, National Pedagogical Dragomanov University, Pirogova str., 9, Kyiv, Ukraine, 01601

E-mail: titnat2008@ukr.net 